\title{
EDITORIAL
}

\section{Academic Learning}

\section{Asking Questions and Judging Answers}

\author{
Lisanne Groen
}

Two years ago, I was teaching an introductory course in administrative law to first-year law students. One of the topics to be discussed was that of the interested party': when one wants to challenge a government decision in court, one has to qualify as an 'interested party'. In order to qualify, different requirements must be taken into account, which are derived mainly from case law.

In preparation for the class, all students had to write an assignment about this subject. I asked one of them how she had approached this specific question and what she thought would be a possible solution. She went over the requirements and argued that the applicant in the assignment could not qualify as an interested party. I complimented her on her answer and asked if anyone had found a different solution. Initially, nobody responded, but after some consideration one of the boys raised his hand hesitantly. He stated that he too had gone over the different requirements, but had decided the applicant could indeed qualify as an interested party, and he explained his decision in great detail. When I complimented him as well, the first student became confused: 'I thought you said my answer was correct, did I misunderstand you?' I said that both of the students had given a suitable answer to the question. 'So... then it's not a very good question, is it?' she responded. For the record: she was not being ironic.

During law school, students have to explore different theories of jurisprudence. They read about Montesquieu's judge, who is nothing more than a 'bouche de la loi'; they study Dworkin's 'right answer thesis'; they read Hart, who claims that Dworkin is a 'noble dreamer' and, if they're lucky, they learn from Posner how judges think and from Kennedy that judges always have political agendas. They also learn that none of these theories is entirely true (or false). At present, students are not generally taught how theories can be put into practice - that is, how they can be useful in solving legal problems. In most academic curricula roughly two types of courses are taught: on the one hand, courses that focus on positive law (students have to solve a case by means of standing law); on the other hand, courses that focus on legal theories (legal philosophy, ethics, theory of jurisprudence, and so on). The two types are hardly ever combined, which may give students the idea that they are unrelated. The question about the 'interested party' in my class was a matter of positive law and therefore only one answer could be correct: the answer in accordance with standing law. 
In my opinion, the student's observation concerns one of the most fundamental issues we have to teach law students: there are always several answers to legal questions. This may confuse them (especially first-year students, because they're not familiar with legal language yet), but it is an essential insight to acquire in order to become a good lawyer. However, the fact that legal issues can be resolved in different ways does not mean that all these solutions are equally suitable. It is therefore particularly important that students learn to distinguish a 'good solution' from a 'possible solution'.

But how do we do that? This issue is all about academic learning and contains several suggestions to optimize legal education in addition to useful insights in academic teaching.

Sohki-Bulley also stresses the importance of a critical attitude. She links this attitude to 'curiosity' and 'self-reflection', and suggests a 'toolbox of skills' that academic teachers can use to teach their students how to be critical, while instructing them in different theories that are part of that toolbox. Methodology is thus interpreted as a way of thinking (an attitude) that always influences the way in which a specific case is approached. Sokhi-Bulley also describes a learning experiment: she asked her students to write an assignment about the same case from different perspectives, for example from a legal positivist, a feminist and a Foucauldian point of view.

While Struiksma creates a theory of dogmatic academic education as such, Van Klink and De Vries, Sokhi-Bulley, Hutchinson and Schwöbel-Patel, in short, focus on what students need to know - and how they should be taught that knowledge - to become good lawyers.

Struiksma investigates how the evolution of the application of mundane knowledge to theory design is 'emulated' in legal dogmatic education. On the basis of the 'empirical cycle' of De Groot, he distinguishes six steps by which theory development takes place: initiation by practical applications; deepening by practical application; recognition of theory design; initiation into theory design; deepening of theory design and independent theory design. Students must become aware of this theory and its development, so they can eventually improve it. That is why the different steps of the empirical cycle should be made more visible in the legal curriculum.

Van Klink and De Vries state that it is important for law students to develop a critical attitude. They introduce the idea of 'skeptical legal education', based, in part, on Oakeshott's understanding of liberal learning. Students have to judge the information they receive, and to optimize the conditions for them to be able to do so. Van Klink and De Vries identify a number of preconditions: student participation has to be emphasized in legal courses, teachers should make clear on the basis of which values they are reasoning, and present a variety of opinions, so that students will discover that legal science is a matter of debate. The result will be an interesting learning experiment that is also suitable for first-year students. 
Hutchinson argues that it is important for lawyers to know how facts are established in the social sciences. Since the assessment of facts is important in interpreting and developing law, lawyers need to be trained in analysing data. This training will result in well-founded legislation and jurisprudence and can be of use in interdisciplinary research groups.

Finally, Schwöbel-Patel describes the course of events during a teaching workshop where she and her colleagues were discussing the possibilities of teaching law in a critical fashion, and the academic restraints in doing so. She gives a rough sketch of these restraints: universities are viewed as enterprises, students as their consumers, and education has to be 'sold' as a financial investment in the student's future. Referring to Kennedy, she emphasizes the dangers of this development and advocates a different, wider understanding of education, which she refers to as Bildung.

The student who got confused two years ago eventually began participating in the discussions in class, a bit wary at first, but gradually more enthusiastically. When I asked her how that enthusiasm had developed, she answered: 'I'm no longer afraid that I'm saying something stupid when I disagree with the others. I've become more confident, not only as a student but also... as a person, I guess.'

Now that's what we need. 